\title{
Balancing the Female Identity in the Construction Industry
}

\author{
*Adedeji Afolabi', Opeyemi Oyeyipo², Rapheal Ojelabi' and \\ Tunji-Olayeni Patience ${ }^{1}$
}

Published online: 31 December 2019

To cite this article: Adedeji Afolabi, Opeyemi Oyeyipo, Rapheal Ojelabi and Tunji-Olayeni Patience (2019). Balancing the female identity in the construction industry. Journal of Construction in Developing Countries, 24(2): 83-104. https://doi. org/10.21315/jcdc2019.24.2.4.

To link to this article: https://doi.org/10.21315/jcdc2019.24.2.4

\begin{abstract}
The fundamental rights of equity and justice call for a balance in the identity of both males and females in every sector. In spite of several strategies aimed at increasing women engagement, the female identity is still blurred in the construction workplace scenery. The study evaluated measures to balancing the female identity in the construction industry. The dataset was obtained through a questionnaire instrument of 105 women in the construction industry. The data were presented using stacked bars, cross tabulation/mean score, principal component analysis (PCA) and one-way analysis of variance (ANOVA). The study revealed that anti-feminine characteristics exist in the industry in form of work growth gap, position/pay gap and symbolic intimidation. The study showed that there is the need for attitudinal changes in the bullying culture and the sexual orientation towards co-workers. Strategies to balance the female identity can be achieved at the national level, construction organisation level, union level and client level. In conclusion, the female identity can be balanced in the construction industry by encouraging adequately funded female mentors/role model programmes. The study recommended that beyond legislation, the onus is on women to inspire women. In order to attract, retain women and reduce the anti-feminine characteristics in the construction sector, there is a need for female mentors/role models to be actively engaged. Strategies and approaches that can alter a female-biased attitude need to be engaged in the minds of construction professionals.
\end{abstract}

Keywords: Construction industry, Female, Gender equality, Legislation, Mentors

\section{INTRODUCTION}

Gender equality is a fundamental human right (Ghailani, 2009). Progress toward gender equality and women's empowerment is a prerequisite for realising human rights and achieving inclusive development, democratic governance, social and economic justice and peace for all. Although there has been a struggle in trying to deliver this singular right to women and girls across all disciplines, in the goodwill of several countries and international bodies, diverse legislation and policies have been directed at balancing the female identity and increasing the representation of women in the political, economic, social and cultural aspects of life. These gender equality policies have tried to use both "hard and soft laws", through legallybinding statutory or regulatory norms, the power of persuasion, the spread of good practice and convergence objectives. A review of the history and development of gender mainstreaming at international levels showed that the important building

\footnotetext{
'Covenant University, Ota, Ogun State, NIGERIA

${ }^{2}$ Bells University of Technology, Ogun State, NIGERIA

*Corresponding author: adedeji.afolabi@covenantuniversity.edu.ng
} 
blocks started over 30 years ago in Nairobi, Africa at the 3rd United Nations (UN) World Conference on Women. The legislation criticised the status quo and called for stronger integration of women in the mainstream of the development process on the same basis as men. Furthermore, the 4th UN World Conference on Women in Beijing held in 1995 agreed by 185 countries gave birth to concepts to promote active and visible programmes for equality between women and men in 12 critical topic areas. This agreement was subsequently assessed to measure the level of progress in the year 2000 and 2005. The 50th session of the UN Commission of the Status of Women (CSW) took place in New York from 27th February to 10th March 2006 and, among other things, demanded equal participation of women and men in decision-making processes at all levels. These equality policies have developed gradually over several decades, taking in new areas and new commitments.

This study posits that legislation, although vital, is not in itself sufficient to attain gender equality. This is true in that, in spite of the numerous efforts by international bodies and NGOs, gender inequality still gravely subsists in many sectors. Ghailani (2009) argued that women are still under-represented in decision-making bodies, both in companies and in society. This difference in opportunities to rise to positions of greater responsibility is now commonly referred as the "glass ceiling", which prevents women from reaching the highest positions, regardless of their abilities, this prevents them being treated on an equal footing with men.

In some quarters, the cultural positions of women being identified as "mother" and "wife" have constrained most women from working outside their homes (Arslan and Kivrak, 2004). The cultural barrier could be weakened further if men come to accept the responsibility of looking after the home front like women do. Maclsaac and Domene (2014) stated that feminist theorists agree with social cognitive theorists that society and social norms have an enormous influence on career development. This is an interaction of behaviour, personal factors and the environment whereby an individual learns through observations of the environment and how others react in the environment. There is a need for radical change in mentalities and in sociocultural references in relation to gender discrimination. Beyond legislation, this change must begin with the general public, since the views of ordinary citizens can influence the political priorities of the national authorities that they elect. This study idealised that attitude is a behaviour that can be learned and unlearned, therefore, there must also be a change of attitude among employers, since they can take direct action to eliminate differences in employment practice.

An important sector that has constantly experienced an imbalance in the supply of workers in both sexes is the construction industry. The study by Afolabi et al. (2017) revealed that the female population represents one of the greatest untapped resources for economic growth and revitalisation in most sectors. It would be unwise not to tap into these vast resources, in a vital industry that contributes to the economies of nations and to the specific livelihoods of families. This crucial and strategic importance requires that the contributions of women should not be ignored. The imbalance in the female identity is not only about increasing the number of women in the construction industry but dealing with other issues such as discrimination, under-recognition, sexual harassment, underemployment and gender pay gap. Watkins (2008) reported that women are often paid less than men for work of equal value. According to the Australian Government Department of Gender Equality Agency, 5.6\% of women working in the construction industry in Australia were underemployed (Workplace Gender Equality Agency, 2016), referring to the situation where a person is working fewer hours when they are willing 
and available to work for more hours. This type of discrimination is usually based on "horizontal occupational segregation by sex" (Watkins, 2008).

Many studies have been focused on attracting and retaining, barriers to entry and development of women in the construction industry. However, this study posits that the problem of inequality lies in the names that identify the culture of the industry. Identity such as "male-dominated", "macho", "patriarchal", "locker room", etc. are status quo that needs to be tackled for there to be a balance in the construction industry. The attitude and atmosphere that exist in the construction industry can be termed women un-friendly. Although the construction industry is the largest employer of labour (Adeyemi et al., 2006; Afolabi et al., 2016), most of its employees are men. Kehinde and Okoli (2004) found that employers prefer male employees or at best young, single professional women. Despite efforts through national and international equality policies, the inequalities remain (Sang and Powell, 2012). The construction industry is territorial in nature, with a reluctance to accept women's identity and skills. In the study by Wilkinson (1992), 20\% of construction stakeholders in the United Kingdom thought that women are a distraction on construction sites and that supervision was a man's job. This constructs a major barrier to entry, development and retention of women in this sector (Amaratunga et al., 2006). Powell, Dainty and Bagilhole (2010) opined that for the construction industry to experience real progress, there is an active need to challenge the realities of a patriarchal construction industry. The construction industry should be driven by performance rather than masculinity because one matters while the other does not count. In spite of the limited studies on women in the construction industry, this study brings to fore the attitude that women perceive from the workplace, workers and its employers in terms of gender bias. Therefore, the study intends to evaluate measures to balance the female identity in the construction industry. The study would be guided by three main research questions which are:

1. What are the anti-feminine characteristics prevalent in the construction industry?

2. Which changes are needed for equality among genders in the construction industry?

3. How can the female identity be balanced in the construction industry?

\section{Underrepresentation of Women in the Construction Industry}

According to Ericksen and Schultheiss (2009), a society that endorses gender equity needs to address gender imbalances. The construction industry is typically a maledominated industry and presents a major challenge for equal opportunities for women (Amaratunga et al., 2006). Women have continued to be underrepresented in the construction industry sector which has been regarded traditionally as stereotypically "male" occupations. The Construction Industry Training Board (2003) cited in Amaratunga et al. (2006) reported that women only account for $9 \%$ of the construction workforce in the United Kingdom where $84 \%$ of these women hold secretarial posts, $10 \%$ are employed in a professional capacity and the remaining $6 \%$ are craft and trade level employees (Amaratunga et al., 2006). In Australia, as of February 2015, only $11.1 \%$ of the workforces in the construction industry are female, with $5.3 \%$ employed full time and the remaining $5.8 \%$ part-time (Australian Government Department of Employment, 2016). A breakdown of some developed 
and developing countries show that women employed in construction are stratified as follows: $2 \%$ in Canada (Statistics Canada, 2007), $9 \%$ in the United States (United States Bureau of Labour Statistics, 2013), $7 \%$ in Turkey (Arslan and Kivrak, 2004), $0.2 \%$ in Nigeria (Jimoh et al., 2016) and an average of 10\% across majority of the European Union countries (Aulin and Jingmond, 2011). This means construction continues to be a most male-dominated industry.

\section{Anti-Feminine Characteristics in the Construction Industry}

The predominant image portrayed in the construction sector is one requiring brute strength and a good tolerance for outdoor conditions, inclement weather and bad language (Agapiou, 2002). It is principally this fallacious image that makes the women uninterested in the industry (Amaratunga et al., 2006). Pearson (1991) found that there is no physical reason why women should not do manual work in the construction sector. According to action research undertaken by Fielden et al. (2001), the participants complained about the identity of the construction industry such as a male-dominated, macho image symbolised by "the builders bum" or "Stratford smile". Dainty, Neale and Bagilhole (2000) found that women may not remain in the industry after education due to the poor initial understanding of the culture of the industry and the inherent difficulties of working in such a maledominated environment. The construction industry displays a macho culture where relationships are characterised by argument, conflict and crisis (Gale, 1994). Bagilhole, Dainty and Neale (2000) noted that the construction work-place has been described as amongst the most chauvinistic in the UK, with an extremely macho culture which is hostile and discriminatory towards women. This macho environment, which is also expressed in more disturbing terms and sexual harassment within the construction industry, is a real concern with almost all reports on women in the industry acknowledging this problem (Construction Industry Board [1996] cited in Amaratunga et al. [2006]).

Davey et al. (1998) highlighted that in the construction industry, male values are the norm such as long working hours, competition, independence, full-time working and that rewards and the expectations for career achievement are paramount. In spite of the consistent association of on-the-job development and promotion, research indicates that women are offered fewer developmental experiences than men (Wernick, 1994). Dainty et al. (2000) found out that male managers use discriminatory recruitment practices which put many women off applying for new positions with contracting organisations. Similarly, the over-emphasis on "male values" of the industry which include long working hours, working away from home and geographical instability and a highly competitive culture which is in contrast to alternative working arrangements such as part-time working, career breaks and job sharing are considered as feminine and unfeasible in the industry (Amaratunga et al., 2006).

\section{Barriers to Women Participation in the Construction Industry}

It is found that women are confronted by a significant number of barriers. From literature survey the major barriers have been identified as the image of the industry, career knowledge, culture and working environment, family commitments, maledominated training courses and recruitment practices (Dainty et al., 2000; Fielden 
et al., 2001; Afolabi et al., 2016), gender role socialisation, stereotyping, discrimination and sexual harassment are some of the cultural and institutional impediments to the choice of working in the construction industry for women (Ericksen and Schultheiss, 2009). Bagilhole, Dainty and Neale (2002) noted that the sexual harassment experienced by women in this sector can range from a verbal request for intimacy, sexual categorical remarks and non-verbal display such as sexual assault, touching and posturing. Maddock and Parkin (1994) and Collier (1995) opined that these sexual references are consciously and purposely made by men to confirm the dominant male heterosexuality and to keep intruders out of what they see as a male preserve. Other issues include negative perceptions of women capabilities (Chun, Arditi and Balci, 2009), minimal recognition on project sites (Menches and Abraham, 2007), expectations to mimic males aggressive behaviours (Maskell-Pretz and Hopkins, 1997), absence of positive influences such as lack of role models/ mentors (Yates, 2001), difficulty in finding a balance between personal goals and professional goals (quality of work life, family/work life balance) (Hatipkarasulu and Roff, 2011), slow career progression (English and LeJeune, 2012), high stress levels linking to career, lack of recognition and encouragement from supervisors, asked to do repetitive minor tasks, undervalued and low potential for career advancement (Loosemore and Waters, 2004) and misjudged on performance compared with male counterparts.

\section{The Need to Balance the Female Identity in the Construction Industry}

Apart from the equality campaign in terms of human rights, for women to have equal representation in the construction industry, other needs stand out as a rationale for balancing the female identity in the construction industry. Ezegbe and Akubue (2012) stated that women possess an unequal amount of potential required for national development. The World Economic Forum (2016) added that consideration of gender parity in any sector could result in enhanced innovation, decision making and expand the talent pool. In the summation of Ely and Thomas (2001), diversity engenders effectiveness, sustainable growth and development. The study by Afolabi et al. (2017), which identified socio-economic benefits in the participation of women in green construction recognised the family/women related benefits, environment-related benefits and the green energy market-related benefits. The need for increased efforts to attract more women into the trades and construction is clearly evident.

According to Munn (2014), there are serious problems on the horizon for the construction industry. Approximately one in five workers are approaching retirement age and a further $26 \%$ is almost 55 years old; replacing these retirees alone presents a big recruitment challenge. In addition, the rising housing need fuelled by an explosive world population growth requires construction workers that are able to fulfil that need. Another issue is the shortage of skilled labour which can be reduced recruiting and retaining women to meet future demands (Menches and Abraham, 2007). Munn (2014) argued that this is a good opportunity to tackle inequality that exists in the construction industry.

With women accounting for a significant percentage of the world's population, Adogbo, Ibrahim and Ibrahim (2015) concluded that it would be wasteful to talk of development in the construction industry when women participation is not being meaningfully and effectively integrated into its development processes. 
Occupations in trades and construction are feasible pathways out of poverty for single mothers, female welfare recipients transitioning from welfare to work and other working women (Mastracci, 2003). Maclsaac and Domene (2014) opined that construction skill trades provide a practical option for women experiencing financial pressure because the trades require less formal education while providing financial compensation even during the apprenticeship process. Not only is working in the construction sector a valid pathway out of poverty, it can provide satisfaction and fulfilment for many women (Ericksen and Schultheiss, 2009). As more women enter these occupations, greater opportunities will emerge for women to advance into supervisory positions and further shape how women experience this type of work (Schroedel, 1990). Evidence shows that gender diverse workplaces tend to be more productive and deliver better returns to the company's bottom line (Prime Minister of Australia, 2016). Without gender diversity, the construction industry is missing out on attracting and retaining the best talent (Prime Minister of Australia, 2016). Greenhaus and Callanan (1994) stated that there are good reasons for encouraging workforce balance within traditionally male-dominated sectors; proponents of diversification argue that it leads to more broadly informed, adaptable organisations, which are closer to customers, more responsive and more able to attract better quality employees. Balancing the female identity could also act as a way of retaining role models and mentors for women considering construction careers in the future (Sang and Powell, 2012). It is worthy to note the claims in Jimoh et al. (2016) that women are detail oriented and this skill is required in project control/management in the construction process. Furthermore, Jimoh et al. (2016) stated that from experience, women executives are better communicators, more effective in decision-making and seek less personal glory than their male counterpart.

\section{RESEARCH METHOD}

The research aimed at examining the anti-feminine characteristics, change towards equality and measures to balance the female identity in the construction industry. The paper presents the female stance by prioritising the perspectives of women respondents as utilised in studies such as Sang and Powell (2012) and Afolabi et al. (2017). The intention is to give women a voice to describe the construction industry from a female standpoint. As Sang and Powell (2012) noted that doing so enables for a rich analysis for the subject under study. The study engaged a quantitative angle to obtain answers to the questions posed by the study. Previous studies supporting the choice of the methodology include Adogbo et al. (2015) and Rosa et al. (2017). A survey research method was utilised with a structured questionnaire instrument in order to elicit information from the respondents of the study. The data instrument had four sections which included the background information of the respondents, the prevalent anti-feminine characteristics, changes that should occur towards gender equality issues and measures to balance the female identity in the construction industry. The respondents for the study were women in the construction industry. This consists of women practising in the fields of architecture, building technology, quantity surveying and engineers and are deemed rich source of information in the construction sector with several years of experience. In selecting the sample size for the study, a purposive sampling technique was used due to the inability to obtain a comprehensive list of both population and the specific characteristics of the respondents. The respondents were selected from 
the Southwestern region of Nigeria, notably Lagos and Ogun State. These study areas have a high concentration of ongoing construction projects which attracts construction professionals to either reside or work within the region. The states have a high investment in housing and urban infrastructures compared to other states in Nigeria. A total of 150 questionnaires were distributed by email and in hard copy to women working in the construction industry. Through consistent follow up, a total of 105 questionnaires were returned, scrutinised and observed to be free of errors. The responses of the 105 participants were used as the basis of this study, which represented $70 \%$ response rate and is deemed adequate for the study. The data collected were in turn tested and analysed using Statistical Package for Social Sciences (SPSS) v.17 software. The data were presented using stacked bars, mean score, principal component analysis (PCA) and one-way analysis of variance (ANOVA).

\section{FINDINGS AND DISCUSSION}

This section is divided into four sub-divisions which highlighted the background of information and the objectives of the study. Furthermore, the results were discussed as corroborated in different literatures. Statistical tools such as stacked bars, PCA, mean scores and ANOVA were used to present the result of the findings.

\section{Demographic Information of Respondents}

The respondents represented women construction workers actively involved in the construction industry in different capacities. A breakdown of the respondents is shown in Figure 1. Figure 1 revealed the summary of the demographical outline of sample group that participated in the study. From Figure 1, the professional background of the respondents are architects $=29(27.6 \%)$, professional builders $=23(21.9 \%)$, civil engineers $=21(20 \%)$ and quantity surveyors $=32(30.5 \%)$. This showed that builders had the highest participation in the study. The highest academic qualification of the women construction professionals showed that most of the respondents have Bachelor's degree. The breakdown of the qualification is as follows: national diplomas $=18(17.1 \%)$, bachelor's degree $=38(36.2 \%)$, master's degree $=42(40 \%)$ and doctoral degree $=7(6.7 \%)$. Figure 1 showed that $72(68.6 \%)$ of the respondents had between 1 to 10 years working experience in the construction industry while 17 (16.2\%) had 11 to 20 years working experience, 15 (14.3\%) had 21-30 years working experience and only $1(0.9 \%)$ had above 30 years working experience in the construction industry. The breakdown of the demographical outline of sample group showed that the respondents had adequate experience to contribute to the subject. 


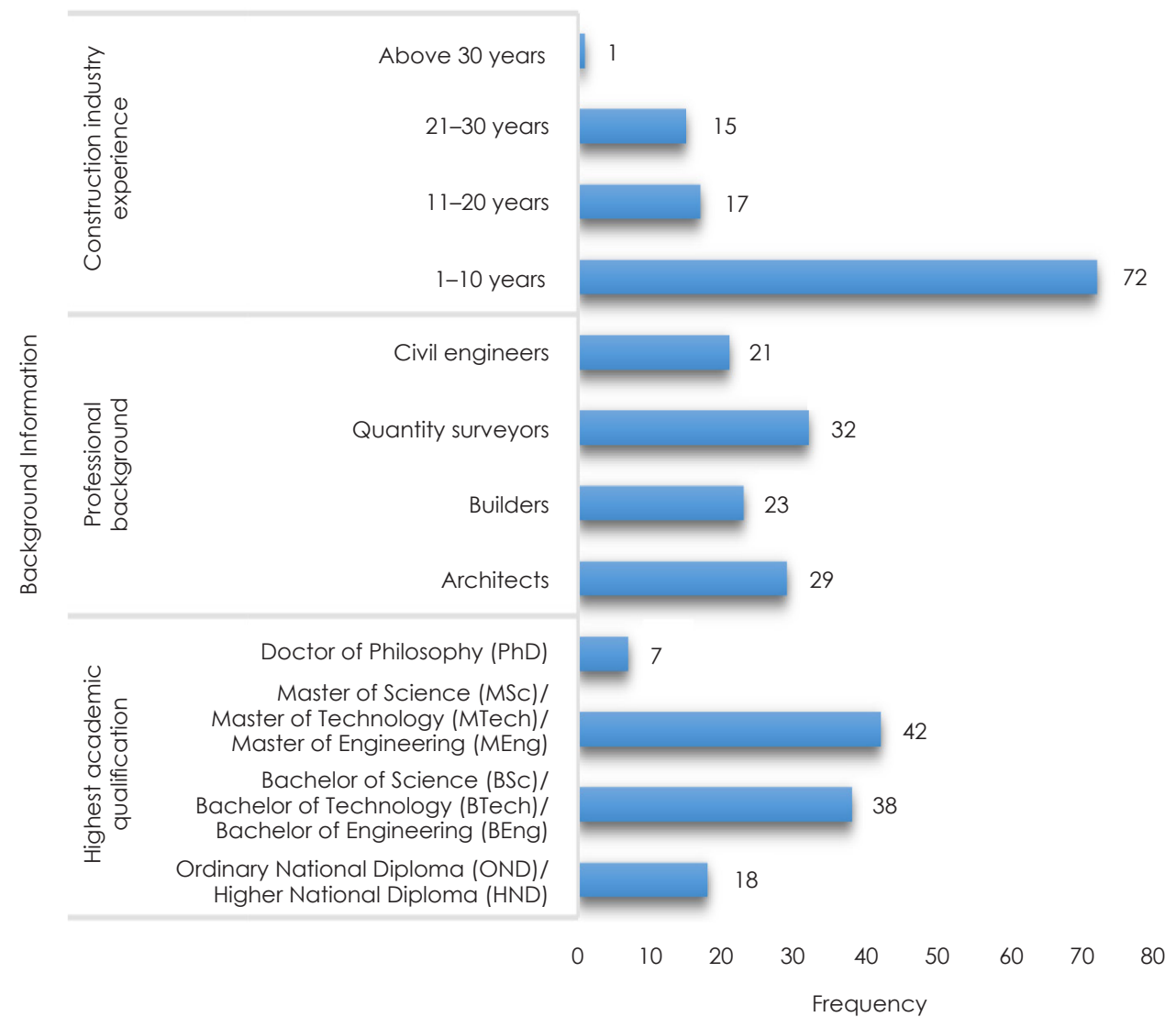

Figure 1. Summary of Demographical Outline of Sample Group

\section{Anti-Feminine Characteristics Prevalent in the Construction Industry}

This section identified anti-feminine characteristics pervading the construction industry as observed from literature. The study used PCA in order to categorise the anti-feminine characteristics. By using PCA, the dimensions of the data are reduced by merging and removing attributes that correlate or those that have dimensions lower than the criteria of 0.5. By reducing the dimensions strong patterns are shown in the groupings for the original dataset. Table 1 showed the PCA for the antifeminine characteristics prevalent in the construction industry. Table 1 showed there are three major principal components illustrated as PCA1, PCA2 and PCA3.

In PCA 1, there are five variables that make up this group. PCA 1 has been termed "work growth gap" as a result of the variables such as the inability to balance personal and career goals, low career advancement, macho culture, intolerable working conditions and the expectations to mimic male aggressive behaviour. This suggests that if one variable increases, then the remaining ones tend to increase as well. PCAl which is the first principal component correlates strongly with an inability to balance personal and career goals and low career advancement. 
This component is centred more on the limitation towards the career growth for women in the construction industry. As it is, this has become one of the characteristics that define the career path for women in the profession.

Table 1. Anti-Feminine Characteristics Prevalent in the Construction Industry

\begin{tabular}{lrrr}
\hline \multirow{2}{*}{ Anti-Feminine Characteristics } & \multicolumn{3}{c}{ Dimension } \\
\cline { 2 - 4 } & PCA1 & PCA2 & PCA3 \\
\hline Inability to balance personal and career goals & 0.917 & -0.043 & -0.142 \\
Low career advancement & 0.917 & -0.043 & -0.142 \\
Macho culture & -0.636 & -0.041 & 0.364 \\
Intolerable working conditions & -0.596 & 0.051 & -0.083 \\
Expectations to mimic male aggressive behaviour & -0.570 & 0.041 & 0.428 \\
Restriction in rising to specific positions & 0.227 & 0.711 & 0.188 \\
Assigning of minor works & -0.319 & -0.659 & -0.230 \\
Lack of respect for women & 0.401 & -0.606 & -0.154 \\
Inflexible working hours & 0.294 & -0.586 & -0.199 \\
Restriction on type of clothing & -0.365 & 0.573 & -0.178 \\
Discrimination in wages (pay gap) & 0.403 & 0.530 & -0.025 \\
Negative perception of women capabilities & 0.336 & -0.410 & .569 \\
Belief that construction women are a threat to men & -0.382 & -0.460 & -0.564 \\
Sexual harassment & 0.488 & -0.038 & 0.562 \\
Under-recognised/Under-employed & -0.004 & -0.158 & 0.544 \\
Discrimination due to family/children issues & -0.013 & -0.208 & 0.528 \\
Male dominance culture & -0.104 & -0.164 & 0.520 \\
Inability to compete with male counterpart & -0.157 & -0.246 & -0.516 \\
\hline
\end{tabular}

PCA 2 represents the second group and has six variables that make the list. PCA 2 has been termed "position/pay gap" as a result of variable such as restriction in rising to specific positions, assigning of minor works, lack of respect for women, inflexible working hours, restriction on the type of clothing and discrimination in wages (pay gap). This principal component has to do with the discrimination about positions that can be occupied by women in the construction organisational structure and the remuneration they should be given in return. PCA2 strongly correlates with the original variable of restriction in rising to specific positions.

PCA 3 represents the third group and has variables such as negative perception of women capabilities, belief that construction women are a threat to men, sexual harassment, under-recognised/under-employed, discrimination due to family/children issues, male-dominance culture and inability to compete with the male counterpart. This group has been termed the "symbolic intimidation". This principal component correlates with the original variable of the negative perception of women capabilities. This showed that when this principal component increases 
other components within this group increases also. This means that under-recognition of women capabilities, negative perception of women capabilities would lead to increase in cases of sexual harassment and the continued dominance of the male culture in the construction industry. The anti-feminine features as summarised from this result showed a leaning towards a discrimination or limitation in career growth, position, wages and symbolic intimidation of women in the construction industry.

This result is corroborated by several studies (Amaratunga et al., 2006; Azhar and Griffin, 2014; Adogbo et al., 2015). Findings from Azhar and Griffin (2014) showed that the top five barriers/challenges in their study were work/life balance (64.3\%), unfair perception of women's capabilities (62.5\%), male-dominated culture (60.7\%), slow career progression (51.8\%) and sexual harassment (41.1\%). Kehinde and Okoli (2004) found that the participation of women in construction is impeded largely by discrimination in employment/promotion, a situation where employers prefer male employees or at best young, single professional women. This is encouraged by the notion that women do not to have the wherewithal to succeed in the construction industry (Adeyemi et al., 2006). This is a misconstrued and flawed prejudice by employers and male counterparts. These studies have in one way or the other primarily identified the anti-feminine and cultural image portrayed by the construction industry as a "no place for women". It is important to study these barriers, as these barriers are responsible for the imbalance in the construction sector while men continue to ride on the image of a "male-dominated industry". It is worthy to note that a call for equal participation in the construction industry is a call for human rights.

The unfair imbalance posed by barriers such as negative perceptions of women capabilities, difficulty in finding a balance between personal goals and professional goals, slow career progression and low potential for career advancement are linked to the findings of this study which portrays an image of a "non-female" industry. All these barriers are not women self-inflicted but are characteristics which the industry constructs as stumbling blocks and ensures that women do not succeed in the industry. Dainty et al. (2000) opined that it is an intentional act by men to maintain their position and image of a "male-dominated industry" by downplaying the contributions of women. In terms of the capacity that women occupy, Adeyemi et al. (2006) reported that women have been limited to administrative positions with the proportion of female administrative staff at $38 \%$ to $62 \%$ for male. This is the only category of construction workers where the malefemale ratio is remarkably bridged. By performing this non-physical works, women experience these stereotyped assumptions in construction trades thereby relegating them to low-skill and less productive capacities which restrict their experience on the job.

\section{Changes Necessary for the Promotion of Gender Equality}

According to Worall et al. (2010), attitudes, behaviours and perceptions of construction stakeholder are viewed as being a top barrier to women in the construction industry. The study identified 15 components that require changes from construction stakeholders in order to promote gender equality in the construction industry. The components identified from literature which were in turn tested in this study includes "Bullying culture", "Bad/Foul language", "Sexual orientation to co-workers", "Work-life balance", "Aggressive and competitive nature of industry", "Discrimination at all levels", "Wage equity among sexes", "Focus on performance/ 
ability rather than gender", "Comparison between capabilities of sexes", "Working conditions, i.e. toilet, safety, etc.", "Socio-cultural beliefs", "Leadership commitment", "Societal expectations", "Individual's mindset" and "Belief in women capabilities". Table 2 showed the changes necessary for the promotion of gender equality in the construction industry.

Table 2. Changes Necessary for the Promotion of Gender Equality

\begin{tabular}{|c|c|c|c|c|c|c|}
\hline Component & Architects & Builders & $\begin{array}{c}\text { Civil } \\
\text { Engineers }\end{array}$ & $\begin{array}{l}\text { Quantity } \\
\text { Surveyors }\end{array}$ & $\begin{array}{l}\text { Overall } \\
\text { Mean } \\
\text { Score }\end{array}$ & $\begin{array}{l}\text { Ranking } \\
\text { Index }\end{array}$ \\
\hline Bullying culture & 4.83 & 4.79 & 4.43 & 4.64 & 4.71 & lst \\
\hline $\begin{array}{l}\text { Sexual orientation to co- } \\
\text { workers }\end{array}$ & 4.00 & 4.47 & 4.43 & 4.73 & 4.41 & 2nd \\
\hline $\begin{array}{l}\text { Aggressive and } \\
\text { competitive nature of } \\
\text { industry }\end{array}$ & 3.83 & 4.21 & 4.14 & 4.27 & 4.12 & $3 r d$ \\
\hline Individual's mindset & 3.75 & 3.68 & 3.86 & 3.64 & 3.71 & 4 th \\
\hline Bad/Foul language & 3.67 & 3.37 & 3.86 & 3.82 & 3.61 & 5 th \\
\hline $\begin{array}{l}\text { Belief in women } \\
\text { capabilities }\end{array}$ & 3.50 & 3.42 & 4.00 & 3.64 & 3.57 & 6th \\
\hline $\begin{array}{l}\text { Working conditions: } \\
\text { i.e. toilet, safety, etc. }\end{array}$ & 3.42 & 3.58 & 3.86 & 3.45 & 3.55 & 7 th \\
\hline Discrimination at all levels & 3.58 & 3.63 & 3.29 & 3.36 & 3.51 & 8th \\
\hline $\begin{array}{l}\text { Focus on performance/ } \\
\text { ability rather than gender }\end{array}$ & 3.58 & 3.47 & 3.71 & 3.27 & 3.49 & 9th \\
\hline $\begin{array}{l}\text { Wage equity among } \\
\text { sexes }\end{array}$ & 3.25 & 3.74 & 3.43 & 3.36 & 3.49 & 9th \\
\hline Work-life balance & 3.58 & 3.53 & 3.43 & 3.18 & 3.45 & 11 th \\
\hline $\begin{array}{l}\text { Comparison between } \\
\text { capabilities of sexes }\end{array}$ & 3.58 & 3.37 & 3.29 & 3.18 & 3.37 & 12 th \\
\hline Leadership commitment & 3.33 & 3.58 & 3.14 & 3.27 & 3.20 & 13th \\
\hline Socio-cultural beliefs & 3.00 & 3.05 & 3.00 & 2.91 & 3.00 & 14 th \\
\hline Societal expectations & 2.92 & 2.89 & 3.00 & 3.00 & 2.94 & 15th \\
\hline
\end{tabular}

Using a cross-tabulation of the mean scores across the four construction professionals, Table 2 showed that architects, builders and civil engineers opined that the bullying culture had to change, whereby it ranked 1st among the variables. Among quantity surveyors, sexual orientation to co-workers ranked 1st while a change in the bullying culture ranked 2nd. The overall mean scores from Table 2 revealed that changes were expected in components such as in the "Bullying culture" which had a mean score of 4.71, "Sexual orientation to co-workers" which has a mean score of 4.41, "Aggressive and competitive nature of industry" which had a mean score of 4.12, "Individual's mindset" which had a mean score of 3.71, "Bad/Foul 
language" which had a mean score of 3.61 and "Belief in women capabilities" which had a mean score of 3.57. It can be observed that the agreement on changes that need to occur on several components was above average. Attitudinal changes to the societal changes ranked least in the study. Bagilhole, Dainty and Neale (2002) suggested that men's compliance with the dominant culture can lead to behaviour that undermines the confidence of women construction professionals and isolates them within the workplace. The inevitable result is considerable and continual stress and emotional strain being placed upon the women in the construction profession. This transcends into fear, depression and ultimately impacts on their professional performance and personal life.

In short, the male-dominant construction industry culture (the title which is in itself a bullying term) tends to hinder women's professional development in the following ways: (1) women find it difficult to assume leadership positions and are therefore relegated to clerical works, (2) the "male" culture belittles women's contribution to the construction industry, (3) various rigid rules and discrimination becomes a hindrance to women's career paths (Dainty et al., 2000; Bagilhole, Dainty and Neale, 2002). In a scenario reported by Cooper (2010), a businessman/ politician was exposed in the media for forwarding sexist and racist emails. His response is, "I apologise... I'm in the construction industry". This is the perceived culture of the construction industry that supports anti-women attitudes and actions.

Women in the construction sector are one of the strongest of the human race having to deal with identities such as "male-dominated", "macho", "patriarchal", "locker room", etc., compounded with the rigour of performing their professional activities on a daily basis. The bullying culture essentially is to reinforce the exclusive nature or rights the male gender possesses in the construction industry. The bullying culture is buttressed with the high rate of sexual harassment in different studies. This is because men often see women workers as intruders and use sexual harassment to keep them out of what they see as a male territory. This is a bullying culture where sex is used as a weapon to dissuade the entry and retention of women in the construction industry. This can be likened to reports of rape and gang rape been used in conflict to ensure compulsory migration of families out of their home of residence. In the end, this has dire physical and psychological effect on their victims - women in the construction industry. It is high time that construction women report cases of sexual assault in the industry to the appropriate quarters. By doing this, they are not only empowering themselves but future generations. The onus is therefore on a well-defined legal system that is able to speedily prosecute such cases.

\section{Measures to Balance the Female Identity in the Construction Industry}

In order to balance the female identity in the construction sector, the study identified some strategies that can be used to repair the imbalance. The measures have been identified based on a national level, organisation level, union level and client level. In this way, actions can be taken on the suggested measures and those responsible on the different levels can take actions in order to balance the female identity in the construction industry. Using cross-tabulation of the mean score, Table 3 highlighted the measures of balancing the female identity at different levels. From Table 3, at the national level there should be introduction of female mentors/role models programmes and improved legislation and policies, at the organisation level there is need to increase the quota of women in top management in construction firms, at the union level there is need to push for flexible working conditions for women in 
the construction industry and for the client level, balancing the female identity can be achieved through a clause in contract execution requiring a percentage of women to be employed on the construction project. A review of the overall mean score in Table 3 revealed that a lot has to be achieved at the national level in order to balance the female identity in the construction industry. A one-way between groups ANOVA was conducted to explore the significant measures among the groups. Table 4 showed the ANOVA test for the measures to balancing the female identity in the construction industry. Using the professional background of the respondents, the result revealed that there was a statistically significant difference at the $p<0.05$ level in the measures for the four professions: $F(3,45)=4.109$, $p$-value $=0.012$ in the measure of having female mentors/ role models programmes as a way of balancing the female identity in the construction industry. The result of using female mentor/role models to balance the female identity in the construction industry is supported by several studies (Bagilhole, Dainty and Neale, 2002; Amaratunga et al., 2006; Adogbo et al., 2015; Rosa et al., 2017).

Table 3. Measures in Balancing the Female Identity in the Construction Industry

\begin{tabular}{|c|c|c|c|c|c|c|}
\hline Measures & Architects & Builders & $\begin{array}{c}\text { Civil } \\
\text { Engineers }\end{array}$ & $\begin{array}{l}\text { Quantity } \\
\text { Surveyors }\end{array}$ & $\begin{array}{l}\text { Overall } \\
\text { Mean } \\
\text { Score }\end{array}$ & $\begin{array}{l}\text { Ranking } \\
\text { Index }\end{array}$ \\
\hline \multicolumn{7}{|l|}{ National Level } \\
\hline $\begin{array}{l}\text { Women mentors/role } \\
\text { models programmes }\end{array}$ & 4.67 & 4.79 & 4.86 & 4.45 & 4.69 & 1st \\
\hline $\begin{array}{l}\text { Improved legislations } \\
\text { and policies }\end{array}$ & 4.58 & 4.68 & 4.43 & 4.45 & 4.57 & $2 n d$ \\
\hline $\begin{array}{l}\text { Prosecution of sexual } \\
\text { harassment cases }\end{array}$ & 4.58 & 4.58 & 4.00 & 4.36 & 4.45 & $3 r d$ \\
\hline \multicolumn{7}{|l|}{ Organisation Level } \\
\hline $\begin{array}{l}\text { More women in top } \\
\text { management }\end{array}$ & 3.83 & 3.95 & 4.29 & 4.09 & 4.00 & 5 th \\
\hline $\begin{array}{l}\text { Increased career } \\
\text { mobility }\end{array}$ & 3.75 & 3.47 & 3.43 & 3.82 & 3.61 & 7 th \\
\hline $\begin{array}{l}\text { Attractive career } \\
\text { paths/growth }\end{array}$ & 3.58 & 3.74 & 4.14 & 3.73 & 3.76 & 6 th \\
\hline $\begin{array}{l}\text { Training opportunities } \\
\text { for women }\end{array}$ & 3.42 & 3.26 & 3.43 & 3.45 & 3.37 & 10th \\
\hline $\begin{array}{l}\text { Improved unbiased } \\
\text { recruitment system }\end{array}$ & 3.33 & 2.79 & 3.00 & 3.00 & 3.00 & 12 th \\
\hline $\begin{array}{l}\text { Commitment from } \\
\text { senior managers }\end{array}$ & 3.58 & 3.32 & 3.29 & 3.64 & 3.45 & 8 th \\
\hline $\begin{array}{l}\text { Collaboration } \\
\text { between employers } \\
\text { and schools }\end{array}$ & 2.58 & 2.68 & 3.14 & 2.91 & 2.78 & 14 th \\
\hline
\end{tabular}


Table 3. (continued)

\begin{tabular}{|c|c|c|c|c|c|c|}
\hline Measures & Architects & Builders & $\begin{array}{c}\text { Civil } \\
\text { Engineers }\end{array}$ & $\begin{array}{l}\text { Quantity } \\
\text { Surveyors }\end{array}$ & $\begin{array}{l}\text { Overall } \\
\text { Mean } \\
\text { Score }\end{array}$ & $\begin{array}{l}\text { Ranking } \\
\text { Index }\end{array}$ \\
\hline \multicolumn{7}{|l|}{ Union Level } \\
\hline $\begin{array}{l}\text { Flexible working } \\
\text { conditions }\end{array}$ & 4.17 & 4.47 & 3.57 & 4.09 & 4.18 & 4 th \\
\hline $\begin{array}{l}\text { Broadened thinking } \\
\text { of construction } \\
\text { stakeholder }\end{array}$ & 2.17 & 2.37 & 2.29 & 2.27 & 2.29 & 16th \\
\hline $\begin{array}{l}\text { Increased awareness } \\
\text { about construction } \\
\text { careers }\end{array}$ & 2.92 & 3.37 & 3.14 & 3.18 & 3.18 & 11 th \\
\hline Equal salary schemes & 3.50 & 2.74 & 3.00 & 2.73 & 2.96 & 13th \\
\hline $\begin{array}{l}\text { Support from } \\
\text { professional bodies and } \\
\text { unions }\end{array}$ & 3.42 & 3.37 & 3.43 & 3.36 & 3.39 & 9th \\
\hline \multicolumn{7}{|l|}{ Client Level } \\
\hline $\begin{array}{l}\text { Client request for } \\
\text { equal women } \\
\text { participation in } \\
\text { contract execution }\end{array}$ & 2.58 & 2.79 & 2.57 & 2.55 & 2.65 & 15 th \\
\hline $\begin{array}{l}\text { Sponsorship of female } \\
\text { construction students }\end{array}$ & 2.58 & 1.89 & 1.43 & 1.64 & 1.94 & 17 th \\
\hline
\end{tabular}

Table 4. ANOVA Test on Measures to Balance the Female Identity in the Construction Industry

\begin{tabular}{llrrrrrr}
\hline \multirow{2}{*}{ Measures } & & $\begin{array}{c}\text { Sum of } \\
\text { Squares }\end{array}$ & df & $\begin{array}{c}\text { Mean } \\
\text { Square }\end{array}$ & F & Sig. & Remark \\
\hline Improved legislations & Between groups & 0.472 & 3 & 0.157 & 0.615 & 0.609 & NS \\
and policies & Within groups & 11.528 & 45 & 0.256 & & & \\
\cline { 2 - 8 } & Total & 12.000 & 48 & & & & \\
\cline { 2 - 8 } $\begin{array}{l}\text { Flexible working } \\
\text { conditions }\end{array}$ & Between groups & 1.989 & 3 & 0.663 & 1.277 & 0.294 & NS \\
& Within groups & 23.358 & 45 & 0.519 & & & \\
\cline { 2 - 8 } & Total & 25.347 & 48 & & & & \\
\cline { 2 - 8 } $\begin{array}{l}\text { Increased career } \\
\text { mobility }\end{array}$ & Between groups & 1.061 & 3 & 0.354 & 1.093 & 0.362 & \multirow{2}{*}{ NS } \\
& Within groups & 14.571 & 45 & 0.324 & & & \\
\cline { 2 - 8 } & Total & 15.633 & 48 & & & & \\
\hline
\end{tabular}


Table 4. (continued)

\begin{tabular}{|c|c|c|c|c|c|c|c|}
\hline Measures & & $\begin{array}{l}\text { Sum of } \\
\text { Squares }\end{array}$ & df & $\begin{array}{l}\text { Mean } \\
\text { Square }\end{array}$ & $F$ & Sig. & Remark \\
\hline \multirow{3}{*}{$\begin{array}{l}\text { Attractive career } \\
\text { paths/growth }\end{array}$} & Between groups & 0.043 & 3 & 0.014 & 0.024 & 0.995 & NS \\
\hline & Within groups & 27.018 & 45 & 0.600 & & & \\
\hline & Total & 27.061 & 48 & & & & \\
\hline \multirow{3}{*}{$\begin{array}{l}\text { Women Mentors/Role } \\
\text { models programmes }\end{array}$} & Between groups & 2.238 & 3 & 0.746 & 4.109 & 0.012 & $S$ \\
\hline & Within groups & 8.170 & 45 & 0.182 & & & \\
\hline & Total & 10.408 & 48 & & & & \\
\hline \multirow{3}{*}{$\begin{array}{l}\text { Training opportunities } \\
\text { for women }\end{array}$} & Between groups & 0.115 & 3 & 0.038 & 0.059 & 0.981 & NS \\
\hline & Within groups & 29.272 & 45 & 0.650 & & & \\
\hline & Total & 29.388 & 48 & & & & \\
\hline \multirow{3}{*}{$\begin{array}{l}\text { Improved unbiased } \\
\text { recruitment system }\end{array}$} & Between groups & 0.590 & 3 & 0.197 & 0.144 & 0.933 & NS \\
\hline & Within groups & 61.410 & 45 & 1.365 & & & \\
\hline & Total & 62.000 & 48 & & & & \\
\hline \multirow{3}{*}{$\begin{array}{l}\text { Client request for } \\
\text { equal women } \\
\text { participation in } \\
\text { contract execution }\end{array}$} & Between groups & 0.496 & 3 & 0.165 & 0.329 & 0.804 & NS \\
\hline & Within groups & 22.606 & 45 & 0.502 & & & \\
\hline & Total & 23.102 & 48 & & & & \\
\hline \multirow{3}{*}{$\begin{array}{l}\text { Prosecution of sexual } \\
\text { harassment cases }\end{array}$} & Between groups & 1.204 & 3 & 0.401 & 0.725 & 0.542 & NS \\
\hline & Within groups & 24.918 & 45 & 0.554 & & & \\
\hline & Total & 26.122 & 48 & & & & \\
\hline \multirow{3}{*}{$\begin{array}{l}\text { Commitment from } \\
\text { senior managers }\end{array}$} & Between groups & 0.629 & 3 & 0.210 & 0.343 & 0.794 & NS \\
\hline & Within groups & 27.494 & 45 & 0.611 & & & \\
\hline & Total & 28.122 & 48 & & & & \\
\hline \multirow{3}{*}{$\begin{array}{l}\text { Support from } \\
\text { professional bodies } \\
\text { and unions }\end{array}$} & Between groups & 2.258 & 3 & 0.753 & 0.906 & 0.446 & NS \\
\hline & Within groups & 37.375 & 45 & 0.831 & & & \\
\hline & Total & 39.633 & 48 & & & & \\
\hline \multirow{3}{*}{$\begin{array}{l}\text { Collaboration } \\
\text { between employers } \\
\text { and schools }\end{array}$} & Between groups & 5.643 & 3 & 1.881 & 1.437 & 0.244 & NS \\
\hline & Within groups & 58.888 & 45 & 1.309 & & & \\
\hline & Total & 64.531 & 48 & & & & \\
\hline \multirow{3}{*}{$\begin{array}{l}\text { More women in top } \\
\text { management }\end{array}$} & Between groups & 1.702 & 3 & 0.567 & 0.971 & 0.415 & NS \\
\hline & Within groups & 26.298 & 45 & 0.584 & & & \\
\hline & Total & 28.000 & 48 & & & & \\
\hline
\end{tabular}


Table 4. (continued)

\begin{tabular}{|c|c|c|c|c|c|c|c|}
\hline Measures & & $\begin{array}{l}\text { Sum of } \\
\text { Squares }\end{array}$ & df & $\begin{array}{l}\text { Mean } \\
\text { Square }\end{array}$ & $F$ & Sig. & Remark \\
\hline \multirow[t]{3}{*}{ Equal salary schemes } & Between groups & 1.292 & 3 & 0.431 & 0.529 & 0.664 & NS \\
\hline & Within groups & 36.626 & 45 & 0.814 & & & \\
\hline & Total & 37.918 & 48 & & & & \\
\hline \multirow{3}{*}{$\begin{array}{l}\text { Increased awareness } \\
\text { about construction } \\
\text { careers }\end{array}$} & Between groups & 0.553 & 3 & 0.184 & 0.335 & 0.800 & NS \\
\hline & Within groups & 24.794 & 45 & 0.551 & & & \\
\hline & Total & 25.347 & 48 & & & & \\
\hline \multirow{3}{*}{$\begin{array}{l}\text { Broadened thinking } \\
\text { of construction } \\
\text { stakeholder }\end{array}$} & Between groups & 1.273 & 3 & 0.424 & 0.304 & 0.822 & NS \\
\hline & Within groups & 62.727 & 45 & 1.394 & & & \\
\hline & Total & 64.000 & 48 & & & & \\
\hline \multirow{3}{*}{$\begin{array}{l}\text { Sponsorship of female } \\
\text { construction students }\end{array}$} & Between groups & 2.958 & 3 & 0.986 & 1.310 & 0.283 & NS \\
\hline & Within groups & 33.859 & 45 & 0.752 & & & \\
\hline & Total & 36.816 & 48 & & & & \\
\hline
\end{tabular}

Notes: NS = Not Significant; $S$ = Significant.

Role models, mentors or significant others have been identified in research as the most valuable resource in a women's career development and profession (Ericksen and Schultheiss, 2009). All of the respondents in the study by Adogbo et al. (2015) agreed that it is vitally important to have female role models or mentors that a woman in practice can look up to or follow for her professional development, this gives the opportunity to make better choices. Rosa et al. (2017) noted that role models are beneficial for individuals to learn from by being present and assist with emotional support, verbal encouragement and help navigate through psychological and career-related issues. Amaratunga et al. (2006) argued that for women to be successfully recruited and retained in construction, they need to be "supported, coached and encouraged". The industry needs to ensure that they are sending out the right message, that women can and do, succeed in a career in a construction and they are not just there to fill the current shortage of present. Adogbo et al. (2015) argued that mentoring is important for providing women with the self-confidence and skills to pursue career advancement and promotions. Although, Francis (2017) argued that using female mentors/role models does not advance women's career development in the construction industry but only keeps women construction professionals from leaving the industry. The argument is based on the notion that mentors may not understand the challenges that their mentees are facing, in that, it may be unique to the mentee, while the female mentor may have never passed through such situations before. However, the benefits of using a woman mentor in the industry may be constrained in that there are few women in the construction industry who can be a role model or act as a mentor. This study posits that the present crop of women professionals needs to become active mentors/role models to new entrant and female construction students in order to tackle the imbalance in the construction sector. Attracting girls 
and women into the construction profession is the first and most important step in achieving a balanced female identity. It is not a lost hope as using female mentor can attract young women into the construction profession and help keep them on the job thereby reducing the imbalance. There is need to investigate strategies that can engender career development among women in the construction profession as it can be frustrating when career development is hampered due to men-biased activities.

\section{LIMITATIONS OF THE STUDY}

A feminist approach to the delivery of the study may prove some sort of bias and prejudice in some quarters. For future study, there is need to understand the perspective of women construction workers in a qualitative nature through the use of interviews as this study was limited to the use of a structured questionnaire instrument. Since the study is focused on gender equality, a masculine perspective may be considered in future studies. In addition, the use of female mentors/role models as a medium to balance the female identity needs to be investigated properly in terms of challenges, prospects and how it can be engineered for career development for women construction professionals. Although the proportion of women in the study area may be low compared to their male counterpart, the study suggests the participation of more women construction professionals in future studies.

\section{CONCLUSIONS AND RECOMMENDATIONS}

Whether through a liberal feminist approach (equal opportunities) or a social feminist approach (a gendered division of labour), the study makes a case which seeks to improve the standing of women in the construction industry. The study opined that it is likely that until women form a more significant proportion of the construction industry's workforce, equality rights is unlikely to be forthcoming in the sector. The study revealed that anti-feminine characteristics exist in the industry in form of:

1. Limitations in career growth for women: as inability to balance personal and career goals, low career advancement, macho culture, intolerable working conditions and the expectations to mimic male aggressive behaviour,

2. Position/pay gap: restriction in rising to specific positions, assigning of minor works, lack of respect for women, inflexible working hours, restriction on type of clothing and discrimination in wages (pay gap) and

3. Symbolic intimidation: negative perception of women capabilities, belief that construction women are a threat to men, sexual harassment, underrecognised/under-employed, discrimination due to family/children issues, male dominance culture and inability to compete with male counterpart. 
The study showed that there is the need for attitudinal change in the bullying culture and the sexual orientation towards co-workers. In balancing the female identity in the construction industry, the study showed that:

1. At the national level, there should be the introduction of female mentors/ role models programmes including improved legislation and policies.

2. At the organisation/firm level, there is need to increase the quota of women in top management in construction firms.

3. At the union level, there is need to push for flexible working conditions for women in the construction industry.

4. At the client level, balancing the female identity can be achieved through a clause in contract execution requiring a percentage of women to be employed on the construction project.

Finally, the most significant strategy in balancing the female identity in the construction industry is by engaging female mentors/role models in coaching, encouraging and inspiring new female entrants into the construction industry and female construction students in higher institutions. The following recommendations were arrived at from the study:

1. Beyond legislation, the onus is on women to inspire and encourage women. In order to attract and retain women in the construction sector, there is the need for female mentors/role models to be actively involved from the grassroots (female construction students).

2. Funding should be earmarked for seminars and workshops, spearheaded by female mentors/role models in the construction sector. Such funding can be used to give female construction students scholarships in order to encourage their entry into the construction sector.

3. Strategies and approaches that can alter a female-biased attitude need to be engaged in the minds of construction professionals. In addition, symbolic intimidation through bullying and sexual harassment in the construction industry should be prosecuted. Adequate legislation encouraging women to speak on issues of symbolic intimidation, where perpetrators would be prosecuted should be in place.

\section{REFERENCES}

Adeyemi, A.Y., Ojo, S.O., Aina, O.O. and Olanipekun, E.A. (2006). Empirical evidence of women under-representation in the construction industry in Nigeria. Women in Management Review, 21(7): 567-577. https://doi. org/10.1108/09649420610692516.

Adogbo, K.J., Ibrahim, A.D. and Ibrahim, Y.M. (2015). Development of a framework for attracting and retaining women in construction practice. Journal of Construction in Developing Countries, 20(1): 99-115. 
Afolabi, A., Emeghe, I., Oyeyipo, O. and Ojelabi, R. (2016). Professionals' preference for migrant craftsmen in Lagos State. Mediterranean Journal of Social Sciences, 7(1): 501-508. https://doi.org/10.5901/mjss.2016.v7n1p501.

Afolabi, A.O., Tunji-Olayeni, P.F., Oyeyipo, O.O. and Ojelabi, R.A. (2017). The socioeconomics of women inclusion in green construction. Construction Economics and Building, 17(1): 70-89. https://doi.org/10.5130/AJCEB.v17i1.5344.

Agapiou, A. (2002). Perceptions of gender roles and attitudes toward work among male and female operatives in the Scottish construction industry. Construction Management and Economics, 20(8): 697-705. https://doi.org/10.1080/01446 19021000024989.

Amaratunga, R.D.G., Haigh, R.P., Shanmugam, M., Lee, A.J. and Dona, N.G.E. (2006). Construction industry and women: A review of the barriers. 3rd International SCRI Research Symposium. Delft, Netherlands: Delft University.

Arslan, G. and Kivrak, S. (2004). The lower employment of women in Turkish construction sector. Building and Environment, 39(11): 1379-1387. https://doi. org/10.1016/j.buildenv.2004.03.005.

Aulin, R. and Jingmond, M. (2011). Issues Confronting Women Participation in the Construction Industry. Kampala, Uganda: Makere University. Available at: http://lup.lub.lu.se/record/1834659 [Accessed on 23 March 2015].

Australian Government Department of Employment (AGDE) (2016). Construction Industry Outlook 2015. Canberra: AGDE. Available at: https://cica.org.au/ wp-content/uploads/2015-Construction-Industry-Outlook.pdf.

Azhar, S. and Griffin, M.K.A. (2014). Women in construction: Successes, challenges and opportunities; A USACE case study. 50th ASC Annual International Conference Proceedings. Fort Collins, CO: Associated Schools of Construction (ASC), 1-8.

Bagilhole, B.M., Dainty, A.R.J. and Neale, R.H. (2002). A woman engineer's experiences of working on British construction sites. International Journal of Engineering Education, 18(4): 422-429.

. (2000). Women in the construction industry in the UK: A cultural discord? Journal of Women and Minorities in Science and Engineering, 6(1): 73-86.

Chun, B., Arditi, D. and Balci, G. (2009). Women in construction management. Available at: http://cmaanet.org/files/files/Women_in_CM_eJournal_0609. pdf.

Collier, R. (1995). Combating Sexual Harassment in the Workplace. Buckingham: Open University Press.

Construction Industry Board (CIB) (1996). Tomorrow's Team: Women and Men in Construction, Working Group 8. London: Thomas Telford and CIB.

Construction Industry Training Board (CITB) (2003). Construction Skills Forecast Report. Norfolk, England: CITB. Available at: http://www.citb.co.uk.

Cooper, A. (2010). Video: Paladino apologizes for offensive e-mails. Anderson Cooper 360, 17 September. Available at: http://ac360.blogs.cnn.com/2010/09/17/ video-paladino-apologizes-for-offensive-e-mails/?iref=allsearch [Accessed on 9 September 2017].

Dainty, A., Neale, R. and Bagilhole, B. (2000). Comparison of men's and women's careers in UK construction industry. Journal of Professional Issues in Engineering Education and Practice, 126(3): 110-115. https://doi.org/10.1061/(ASCE) 1052$3928(2000)$ 126:3(110). 
Davey, C., Davidson, M., Gale, A., Hopley, A. and RhysJones, S. (1998). Building Equality in Construction: Good Practice Guidelines for Building Contractors and Housing Associations. Manchester: University of Manchester Institute of Science and Technology (UMIST)/Department of the Environment, Transport and the Regions (DETR).

Ely, R.J. and Thomas, D.A. (2001). Cultural diversity at work: The effects of diversity perspectives on work group processes and outcomes. Administrative Science Quarterly, 46(2): 229-273. https://doi.org/10.2307/2667087.

English, J. and Le Jeune, K. (2012). Do professional women and tradeswomen in the South African construction industry share common employment barriers despite progressive government legislation? Journal of Professional Issues in Engineering Education and Practice, 138(2): 145-152. https://doi.org/10.1061/ (ASCE)El.1943-5541.0000095.

Ericksen, J.A. and Schultheiss, D.E.P. (2009). Women pursuing careers in trades and construction. Journal of Career Development, 36(1): 68-89. https://doi. org/10.1177/0894845309340797.

Ezegbe, B.N. and Akubue, F.N. (2012). An appraisal of the status of Nigerian women: Educational implications and national development. American Journal of Sociological Research, 2(2): 27-31. https://doi.org/10.5923/j. sociology.20120202.03.

Fielden, S.L., Davidson, M.J., Gale, A.W. and Davey, C.L. (2001). Women, equality and construction. Journal of Management Development, 20(4): 293-304. https://doi.org/10.1108/02621710110388956.

Francis, V. (2017). What influences professional women's career advancement in construction? Construction Management and Economics, 35(5): 254-275. https://doi.org/10.1080/01446193.2016.1277026.

Gale, A.W. (1994). Women in non-traditional occupations: The construction industry. Women in Management Review, 9(2): 33-47. https://doi.org/10.1108/ EUM0000000003989.

Ghailani, D. (2009). Gender wage gap as a tension between quality and quantity of jobs in the European labour market. In A.M. Guillén and S.-A. Dahl (eds.), Quality of Work in the European Union: Concept, Data and Debates from a Transnational Perspective. Brussels: PIE Peter Lang.

Greenhaus, J.H. and Callanan, G.A. (1994). Career Management. 2nd Ed. Orlando, FL: Dryden Press.

Hatipkarasulu, Y. and Roff, E.S. (2011). Women in construction: An early historical perspective. In 47th ASC Annual International Conference Proceedings. Omaha, NE: Associated Schools of Construction (ASC).

Jimoh, R.A., Oyewobi, L.O. Adamu, A.N. and Bajere, P.A. (2016). Women professionals' participation in the Nigerian construction industry: Finding voice for the voiceless. Organization, Technology and Management in Construction, 8(1): 1429-1436. https://doi.org/10.1515/otmcj-2016-0005.

Kehinde, J.O. and Okoli, O.G. (2004). Professional women and career impediments in the construction industry in Nigeria. Journal of Professional Issues in Engineering, Education and Practice, 130(2): 115-119. https://doi.org/10.1061/ (ASCE) 1052-3928(2004) 130:2(115).

Loosemore, M. and Waters, T. (2004). Gender differences in occupational stress among professionals in the construction industry. Journal of Management in Engineering, 20(3): 126-132. https://doi.org/10.1061/(ASCE)0742597X(2004)20:3(126). 
Maclsaac, K.M.R. and Domene, J.F. (2014). Learning the tricks of the trades: Women's experiences. Canadian Journal of Counselling and Psychotherapy, 48(1): 1-12.

Maddock, S. and Parkin, D. (1994). Gender cultures: How they affect men and women at work. In M.J. Davidson and R. Burke (eds.), Women in Management: Current Research Issues. London: Paul Chapman Publishing Ltd.

Maskell-Pretz, M. and Hopkins, W.E. (1997). Women in engineering: Toward a barrierfree work environment. Journal of Management in Engineering, 13(1): 32-37. https://doi.org/10.1061/(ASCE)0742-597X(1997)13:1(32).

Mastracci, S.H. (2003). Employment and training alternatives for non-college women: Do redistributive policies really redistribute? Policy Studies Journal, 31 (4): 585-601. https://doi.org/10.1111/1541-0072.00044.

Menches, C.L. and Abraham, D.M. (2007). Women in construction: Tapping the untapped resource to meet future demands. Journal of Construction Engineering and Management, 133(9): 701-707. https://doi.org/10.1061/ (ASCE)0733-9364(2007)133:9(701).

Munn, M. (2014). Building the Future: Women in Construction. London: The Smith Institute, 3-8.

Pearson, J. (1991). Women in Construction. Ascot, Berkshire: The Chartered Institute of Building (ClOB).

Powell, A., Dainty, A. and Bagilhole, B. (2010). Achieving gender equality in the construction professions: Lessons from the career decisions of women construction students in the UK. In C. Egbu (ed.), Procs 26th Annual ARCOM Conference. Leeds: Association of Researchers in Construction Management (ARCOM), 573-582.

Prime Minister of Australia (2016). Supporting women in building and construction. Press release, 27 April. Available at: https://www.pm.gov.au/media/2016-04-27/ supporting-women-building-and-construction.

Rosa, J.E., Hon, C.K.H., Xia, B. and Lamari, F. (2017). Challenges, success factors and strategies for women's career development in the Australian construction industry. Construction Economics and Building, 17(3): 27-46. https://doi. org/10.5130/AJCEB.v17i3.5520.

Sang, K. and Powell, A. (2012). Gender inequality in the construction industry: Lessons from Pierre Bourdieu. In S.D. Smith (ed.), Procs 28th Annual ARCOM Conference. Edinburgh, UK: Association of Researchers in Construction Management (ARCOM), 237-247.

Schroedel, J.R. (1990). Blue-collar women: Paying the price at home and on the job. In H.Y. Grossman and N.L. Chester (eds.), The Experience and Meaning of Work in Women's Lives. Hillsdale, NJ: Lawrence Erlbaum.

Statistics Canada (2007). Employment Indexes, by Sex. Ontario, Canada: Statistics Canada. Available at: http://www.statcan.gc.ca/pub/71-222-x/2008001/ sectionb/b-index-indice-eng.htm.

United States Bureau of Labor Statistics (2013). Employed Persons by Detailed Industry, Sex, Race and Hispanic or Latino Ethnicity. Washington DC: United States Bureau of Labor Statistics. Available at: http://www.bls.gov/cps/ cpsaat 11.pdf [Accessed on 24 December 2013].

Watkins, G. (2008). Gender equality: The forgotten component in employment equity initiatives (part 1). Work info on gender policy and guidelines. 
Wernick, E.D. (1994). Preparedness, career advancement and the glass ceiling. Draft Report to the Glass Ceiling Commission. Washington DC: US Department of Labor.

Workplace GenderEquality Agency (WGEA) (2016). FactSheet: GenderComposition of the Workforce; By Industry. Sydney: WGEA. Available at: https://www. wgea.gov.au/sites/default/files/2014-04-04-Gender composition-of-theworkforce-by-industry.pdf [Accessed on 27 May 2016].

Worrall, L.J., Harris, K., Stewart, R., Thomas, A. and McDermott, P. (2010). Barriers to women in the UK construction industry. Engineering, Construction and Architectural Management, 17(3): 268-281. https://doi. org/10.1108/09699981011038060.

Wilkinson, S. (1992). Career paths, child care: Employer's attitudes towards women in construction. In Proceedings from the Women in Construction Conference. Newcastle upon Tyne, UK: University of Northumbria.

World Economic Forum (WEF) (2016). The industry gender gap: Women and work in the fourth industrial revolution. Executive Summary, January. Cologny/ Geneva: WEF, 1-11.

Yates, J.K. (2001). Retention of non-traditional engineering and construction professionals. Journal of Management in Engineering, 17(1): 41-48. https:// doi.org/10.1061/(ASCE)0742-597X(2001)17:1(41). 